\title{
Energy Characteristics of an Integrated Power Generation System with Photovoltaic and Fuel Cell
}

\author{
Akira Nishimura' ${ }^{1}$, Syota Tanikaga ${ }^{1}$, Masafumi Hirota ${ }^{1}$, Eric $\mathrm{Hu}^{2}$ \\ ${ }^{1}$ Division of Mechanical Engineering, Graduate School of Engineering, Mie University, Tsu, Japan \\ ${ }^{2}$ School of Mechanical Engineering, The University of Adelaide, Adelaide, Australia \\ Email: nisimura@mach.mie-u.ac.jp
}

How to cite this paper: Nishimura, A. Tanikaga, S., Hirota, M. and Hu, E. (2018) Energy Characteristics of an Integrated Power Generation System with Photovoltaic and Fuel Cell. Smart Grid and Renewable Energy, 9, 57-73.

https://doi.org/10.4236/sgre.2018.94005

Received: April 2, 2018

Accepted: April 27, 2018

Published: April 30, 2018

Copyright $(0) 2018$ by authors and Scientific Research Publishing Inc. This work is licensed under the Creative Commons Attribution International License (CC BY 4.0).

http://creativecommons.org/licenses/by/4.0/

\begin{abstract}
An integrated energy system (with photovoltaic (PV) and fuel cell (FC) for building) is proposed and assessed in term of its energy self-sufficiency rate in seven cities (Nagoya, Toyota, Tajimi, Takayama, Ogaki, Hamamatsu, Shizuoka) in Tokai region in Japan in this paper. In this work, it is considered that the electricity requirement of the building for household users is provided by a building integrated photovoltaic (BIPV) system and the gap between the energy demand and BIPV supply is fulfilled by the FC. The FC is powered by the electrolytic $\mathrm{H}_{2}$ produced when PV power was in surplus. Based on the study of applying the proposed system in seven cities, which clarifies the effectiveness of the integrated BIPV, electrolytic $\mathrm{H}_{2}$ and $\mathrm{FC}$ power generation system, a universal system model has been developed in this paper. It has been observed that the monthly power production from BIPV as well as FC system are higher in spring and summer, while they are both lower in autumn and winter at all considered locations. The self-sufficiency rate of the FC system is higher with decreasing households' number and it has been observed that 16 is the most appropriate number of households in a building, whose electricity demand could be fully covered by the integrated PV and FC system. Due to its climate condition, Hamamatsu is the best city in the region for installing the proposed system. The correlation between the households' number and self-sufficiency rate of the FC system per solar PV installation area can be expressed by the regression curve in the form of $y=a x^{-\mathrm{b}}$ well.
\end{abstract}

\section{Keywords}

Smart Building, Photovoltaics, $\mathrm{H}_{2}$ Produced by Water Electrolysis, Polymer Electrolyte Fuel Cell, Self-Sufficiency Rate 


\section{Introduction}

According to Energy White Paper 2017 in Japan [1], it is expected that the global consumption of primary energy will increase by $1.2 \%-1.8 \%$ per year from 2015 to 2030. The renewable energy is expected to be the most increasing energy source. Power generated from renewable energy sources excluding hydro power in 2030 is expected to be $2.1-3.4$ times as large as that in 2015. Though the renewable energy such as solar photovoltaic (PV) has been growing rapidly due to feed-in tariff system introduced in 2012 in Japan, the ratio of the installed capacity as well as the electricity generated of PV system in Japan to those in the world becomes lower. In other words, the growth of renewable energy in Japan is lower than world average. To promote the growth of renewable energy (in Japan), it is important to develop the low cost technology and to solve the problem that the output is unsteadiness due to their intermittent natures.

Recently, the so-called building integrated PV systems (BIPV) have been attracted attention from the world [2] [3]. Systems are integrating/installing solar panels on the roof and/or side walls of a building to meet the energy demand of the building. The studies on power generation characteristics or economy assessment of BIPV considering the climate condition in Singapore [4], Malaysia [5] and Brazil [6] were reported. In addition, the environmental assessment by Life Cycle Assessment of BIPV was also reported [7] [8] [9]. The combined system of BIPV and battery for solving the performance fluctuation of PV due to weather was evaluated from the view point of power generation performance and economy characteristics [10] [11]. It was reported that the conversion into $\mathrm{H}_{2}$ is superior to battery to store the large amount of renewable energy for a long time [12], and there were some reports investigating the combination of PV and electrolytic $\mathrm{H}_{2}$ [13] [14]. Although there were a few research investigating the combination of BIPV, electrolytic $\mathrm{H}_{2}$ and fuel cell power generation system [15] [16] [17], they mainly focused on the system control procedure such as the evaluation on dynamics characteristics of system output [15], the optimization of system output [16] and the evaluation of fussy control effectivity [17]. Therefore, there were few studies other than the authors' group that investigate the power generation characteristics considering the size of the building and climate conditions in the building locations to meet the electricity demand [18]. However, the previous study [18] investigated for only limited cities in one prefecture (in Japan), resulting that the more case studies are needed for clarifying the effectiveness of the combination of BIPV, electrolytic $\mathrm{H}_{2}$ and fuel cell (FC) power generation system and for developing the universal system model.

In this paper, a desk top case study has been performed to simulate a proposed BIPV system with utilization of stored energy in the form of electrolytic $\mathrm{H}_{2}$ and the stored $\mathrm{H}_{2}$ is used to fuel FC to generate the power for a building when the power generated from the BIPV is insufficient for the building. The proposed integrated BIPV + FC system consists of the solar PV array, water electrolyzer and FC. The $\mathrm{H}_{2}$ is generated and stored with the surplus power of 
the BIPV. The FC would therefore be able to buffer the intermittency (partly) between the building electricity demand (by the building) and the PV system. To investigate the impact of local climate condition on the performance of the proposed integrated system, two cities in Aichi prefecture (Nagoya, Toyota), three cities in Gifu prefecture (Tajimi, Takayama, Ogaki) and two cities in Shizuoka prefecture (Hamamatsu, Shizuoka) in Tokai region, Japan have been selected to the locations for the desk-top case study. Their meteorological data are from the project "PV300" (period from August, 2013 to July, 2014) [19]. The BIPV power productions have been compared with the electricity demand data of households [20] and investigated for the optimum power supply in a way to overcome the intermittency of the electricity demand and PV system. The self-sufficiency rate of the proposed BIPV system to electricity demand has been estimated in the design study. In addition, the optimum number of households living in the building, i.e. the optimum size of the building, has been investigated. From the results of this study, the universal BIPV system model which can be applied for different climate conditions is obtained. This can be contributed for promoting the growth of renewable energy.

\section{Design Study}

\subsection{Estimation of Power Generation from the PV System}

The building model, used in the design study, is $10 \mathrm{~m}$ width, $40 \mathrm{~m}$ length and 40 $\mathrm{m}$ height (=10 stories) [21] with 40 households [22]. According to the statistics data collected in Japan [22], the average floor space of dwelling of Japan is about $100 \mathrm{~m}^{2}$ per a household. The height of one floor is assumed as $4 \mathrm{~m}$. Assuming that four households stay per floor, the floor space is $400 \mathrm{~m}^{2}$. This study proposed the building model utilizing the accelerated wind between buildings for a power generation by wind turbine and assessed the power generation performance of wind turbine of $50 \mathrm{~kW}$ class whose height was $39 \mathrm{~m}$ [21]. Since this study considers the application of this building model for combining with PV system in the future, the building size of $10 \mathrm{~m}$ width, $40 \mathrm{~m}$ length and $40 \mathrm{~m}$ height is set at the initial condition. The BIPV system has considered on the roof/top of the building, i.e., with $400 \mathrm{~m}^{2}$ areas, and a $\mathrm{FC}$ using electrolytic $\mathrm{H}_{2}$ produced when there is the surplus power from BIPV [23].

The power generated by PV system is calculated by using the following equation [24]:

$$
E_{P V}=H \times K \times P / 1
$$

where $E_{P V}$ is hourly electric power of PV system $(\mathrm{kW} \cdot \mathrm{h}), H$ is hourly amount of solar radiation $\left(\mathrm{kW} \cdot \mathrm{h} / \mathrm{m}^{2}\right), K$ is power generation loss factor $(-), P$ is system capacity of PV $(\mathrm{kW}), 1$ is solar radiation under standard state (AM1.5, hourly solar radiation: $1 \mathrm{~kW} \cdot \mathrm{h} / \mathrm{m}^{2}$, module temperature: 25 degree Celsius) $\left(\mathrm{kW} / \mathrm{m}^{2}\right)$. The instantaneous solar radiation data by $10 \mathrm{sec}$ of the reference [19] are integrated as hourly data for calculating the hourly electric power of PV system. 
In this study, the high-performance PV P250 $\alpha$ Plus produced by Panasonic has been considered. This module has conversion efficiency and maximum power rating per module is $19.5 \%$ and $250 \mathrm{~W}$ [25]. The size of PV module is $1580 \mathrm{~mm} \times 812 \mathrm{~mm} \times 35 \mathrm{~mm}$. $P$ has been calculated by installing this PV module on the roof of the building model, which is $75 \mathrm{~kW}_{p}$ (=300 solar modules). To calculate $K$, the performance value of state-of-the-art commercial devise is used. $K$ is calculated by using the following equation [24]:

$$
K=K_{p} \times K_{m} \times K_{i}
$$

where $K_{p}$ is power conversion efficiency of power conditioner (-), $K_{m}$ is correction factor decided by module temperature $(-), K_{i}$ is power generation loss by interconnecting and dirty of module surface (-). In this study, $K_{p}$ and $K_{i}$ are set at 0.96 and 0.95 , respectively. $K_{p}$ is assumed by referring to the performance of commercial power conditioning device VBPC259B3 manufactured by Panasonic [26]. $K_{m}$ is calculated by the following equation [24]:

$$
K_{m}=1-\frac{\left(T_{m}-T_{s}\right) C}{100}
$$

where $T_{m}$ is $\mathrm{PV}$ module temperature (degree Celsius), $T_{s}$ is temperature under standard test condition (= 25 degree Celsius) (degree Celsius), $C$ is temperature correction factor which is 0.35 [27] (\%/degree Celsius). The temperature characteristics of PV module which is adopted for this study is referred. $T_{m}$ is calculated by using the following equation [24] [28]:

$$
T_{m}=T_{a}+\left(\frac{46}{0.41 U_{m}^{0.8}+2}\right) H-2
$$

where $T_{a}$ is ambient air temperature (degree Celsius), $U_{m}$ is wind velocity over module of PV $(\mathrm{m} / \mathrm{s})$. In this equation, the convection heat transfer by wind around the PV module is considered.

The meteorological data, such as solar radiation, the ambient air temperature, and wind velocity of the cities involved in the study have been taken from the data base of the project "PV300" for the period from August, 2013 to July, 2014 [19]. Table 1 has listed a sample of PV300 data, which shows the data of air temperature and amount of horizontal solar radiation at $10 \mathrm{sec}$ intervals on 1st August, 2013 for Nagoya in Japan. According to the previous study [24], the optimum tilt angle of solar panel installed on a roof/top of the building is 0 degree, resulting that the horizontal solar radiation has been used for calculating the power generated by the PV system in this study.

\subsection{Estimation of Power Generated by FC System Using $\mathrm{H}_{2}$ Produced by Water Electolysis}

In this study, it has been assumed that the surplus power generated by the PV system over the electricity demand of households [20] living in the considered building, would be used for electrolytic $\mathrm{H}_{2}$ production (i.e. long term energy storage in the form of electrolytic $\mathrm{H}_{2}$ ). To optimize the size of BIPV system, 
Table 1. Sample data of PV300 on 1st August, 2013 for Nagoya in Japan.

\begin{tabular}{|c|c|c|c|c|c|c|c|}
\hline Year & Month & Day & Hour & Min & $\mathrm{Sec}$ & $\begin{array}{c}\text { Amount of } \\
\text { horizontal solar } \\
\text { radiation }\left(\mathrm{kW} / \mathrm{m}^{2}\right)\end{array}$ & $\begin{array}{c}\text { Air } \\
\text { temperature } \\
\text { (degree Celsius) }\end{array}$ \\
\hline 2013 & 8 & 1 & 10 & 0 & 0 & 0.2826 & 26.2 \\
\hline 2013 & 8 & 1 & 10 & 0 & 10 & 0.2828 & 26.2 \\
\hline 2013 & 8 & 1 & 10 & 0 & 20 & 0.2825 & 26.2 \\
\hline 2013 & 8 & 1 & 10 & 0 & 30 & 0.2826 & 26.3 \\
\hline 2013 & 8 & 1 & 10 & 0 & 40 & 0.2822 & 26.3 \\
\hline 2013 & 8 & 1 & 10 & 0 & 50 & 0.2808 & 26.3 \\
\hline 2013 & 8 & 1 & 10 & 1 & 0 & 0.2799 & 26.2 \\
\hline 2013 & 8 & 1 & 10 & 1 & 10 & 0.2777 & 26.2 \\
\hline 2013 & 8 & 1 & 10 & 1 & 20 & 0.2747 & 26.2 \\
\hline 2013 & 8 & 1 & 10 & 1 & 30 & 0.2721 & 26.2 \\
\hline 2013 & 8 & 1 & 10 & 1 & 40 & 0.2690 & 26.2 \\
\hline 2013 & 8 & 1 & 10 & 1 & 50 & 0.2663 & 26.2 \\
\hline 2013 & 8 & 1 & 10 & 2 & 0 & 0.2638 & 26.2 \\
\hline 2013 & 8 & 1 & 10 & 2 & 10 & 0.2617 & 26.2 \\
\hline 2013 & 8 & 1 & 10 & 2 & 20 & 0.2592 & 26.2 \\
\hline 2013 & 8 & 1 & 10 & 2 & 30 & 0.2580 & 26.2 \\
\hline 2013 & 8 & 1 & 10 & 2 & 40 & 0.2576 & 26.3 \\
\hline 2013 & 8 & 1 & 10 & 2 & 50 & 0.2575 & 26.3 \\
\hline 2013 & 8 & 1 & 10 & 3 & 0 & 0.2578 & 26.3 \\
\hline
\end{tabular}

number of households has been varied by $40,20,16$ and 12 which correspond to $10,5,4$ and 3 stories of the building, respectively. In this study, the building which has 4 households per floor is assumed. Then, the multiple number of 4 is based for assessment. To keep a building structure, the lowest limit of stories is set at 3 which is the standard low height building, indicating 12 households. The Type-S electrolyzer manufactured by IHT [29] [30] whose $\mathrm{H}_{2}$ production rate, power consumption and electrolysis efficiency are $760 \mathrm{~N} \cdot \mathrm{m}^{3} / \mathrm{h}, 4.45 \mathrm{~kW} \cdot \mathrm{h} / \mathrm{N} \cdot \mathrm{m}^{3}$ and $79.5 \%$, have been used in this design study. The amount of electrolytic $\mathrm{H}_{2}$ could be produced by the surplus power generated from the PV system is calculated by the following equation:

$$
V_{H 2}=E_{s} / P_{e}
$$

where $V_{H 2}$ is amount of electrolytic $\mathrm{H}_{2}$ produced $\left(\mathrm{N} \cdot \mathrm{m}^{3}\right), E_{s}$ is surplus power generated by $\mathrm{PV}$ system $(\mathrm{kW} \cdot \mathrm{h}), P_{e}$ is power consumption $\left(\mathrm{kW} \cdot \mathrm{h} / \mathrm{N} \cdot \mathrm{m}^{3}\right)$. In this study, it is assumed that the electrolyzer can be operated following the power generation characteristics of PV system every time and the produced $\mathrm{H}_{2}$ can be stored as well as used instantaneously [24].

It has been assumed that the $\mathrm{H}_{2}$ produced by the electolyzer would be used to 
generate power through a polymer electrolyte fuel cell (PEFC) system [24]. $\mathrm{H}_{2}$ is converted into electricity by $\mathrm{FC}$ following the below equation:

$$
\mathrm{H}_{2}+1 / 2 \mathrm{O}_{2}=\mathrm{H}_{2} \mathrm{O}+\eta_{f} Q
$$

where $\eta_{f}$ is power generation efficiency of latest PEFC stationary system based on lower heating value (=0.39) [31], $Q$ is lower heating value of $\mathrm{H}_{2}(=242)$ $(\mathrm{kJ} / \mathrm{mol})$. It is assumed that the energy loss for operating pump to preserve and provide gases is ignored [18]. Figure 1 illustrates the schematic drawing of the proposed integrated BIPV + FC system.

In this study, a monthly self-sufficiency rate of the proposed combination system consisting of the PV and FC has been investigated for Nagoya (Latitude: $35.10^{\circ} \mathrm{N}$, Longitude: $136.54^{\circ} \mathrm{E}$ ), Toyota (Latitude: $35.4^{\circ} \mathrm{N}$, Longitude: $137.9^{\circ} \mathrm{E}$ ), Tajimi (Latitude: $35.19^{\circ} \mathrm{N}$, Longitude: $137.7^{\circ} \mathrm{E}$ ), Takayama (Latitude: $36.8^{\circ} \mathrm{N}$, Longitude: $137.15^{\circ} \mathrm{E}$ ), Ogaki (Latitude: $35.21^{\circ} \mathrm{N}$, Longitude: $136.36^{\circ} \mathrm{E}$ ), Hamamatsu (Latitude: $34.42^{\circ} \mathrm{N}$, Longitude: $137.43^{\circ} \mathrm{E}$ ) and Shizuoka (Latitude: $34.54^{\circ} \mathrm{N}$, Longitude: $138.18^{\circ} \mathrm{E}$ ). They are the main cities in Tokai region located in the center of Japan. The self-sufficiency rate is defined as the power supplied (from the combined PV and FC system) to the electricity demand of the households living in the building. The hourly time change in the self-sufficiency rate in the day, when the daily mean amount of horizontal solar radiation per month has been obtained and estimated.

\section{Results and Discussion}

\subsection{Power Supply Characteristics of the BIPV to the Building Electricity Demand in the Case of 40 Households}

This study has investigated the power production from the PV system using the meteorological data base of PV300 [19] including air temperature, solar intensity and wind speed at $10 \mathrm{sec}$ intervals. Since the electricity demand of households [20] is available as hourly data, the power production from the PV system is

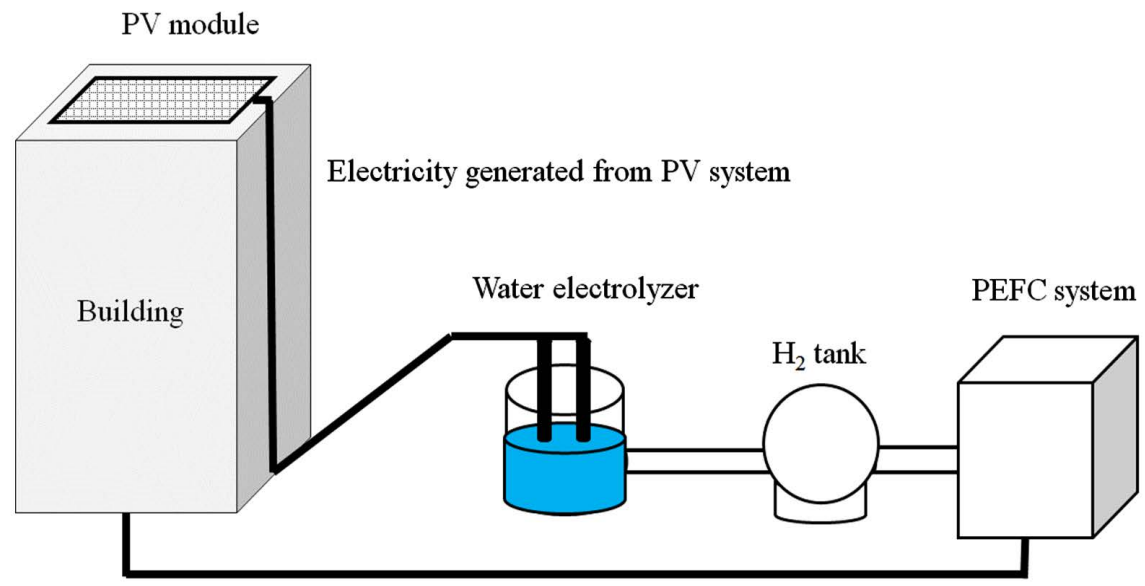

Electricity generated from PEFC system

Figure 1. Schematic drawing of the proposed integrated BIPV + FC system. 
summarized as hourly data by integrating the instantaneous data available at 10 sec intervals.

As an example, Table 2 has listed the hourly power from PV system (installed in Nagoya for a year) which shows the seasonal characteristic of the PV system. From this table, it can be seen the hourly power of PV system increases from the morning up to the noon and decreases from the noon up to the evening as expected. In addition, it is obvious that the hourly power of PV system is higher in spring and summer, while it is lower in autumn and winter. The data shown in the Table 2 has been summed as the typical daily data for the location in the month which then is multiplied by the total days for each month as the monthly data. The monthly power production from the PV system is shown in Figure 2 to investigate the seasonal and local characteristics. It has been observed that the monthly power of the PV system is higher in spring and summer, while it is lower in autumn and winter irrespective of the cities. According to the comparison among seven cities, the monthly power of the PV system from November to January in Takayama is smaller than that in the other cities. In addition, the monthly power of the PV system for Hamamatsu is high through the year. The reasons will be discussed later.

Table 3 has listed the hourly electricity demand of 40 households for a year. In this study, the variation of electricity demand profile for different cities is not considered like the previous study [18]. Namely, the same electricity demand profile has been used for all seven cities in this study. When considering the electricity demand profile of other number of households, the data in Table 3 have been recalculated. It is found that the hourly electricity demand increases from the morning and keeps almost a constant value during a day. After that, the hourly electricity demand increases rapidly from the evening and keeps almost a

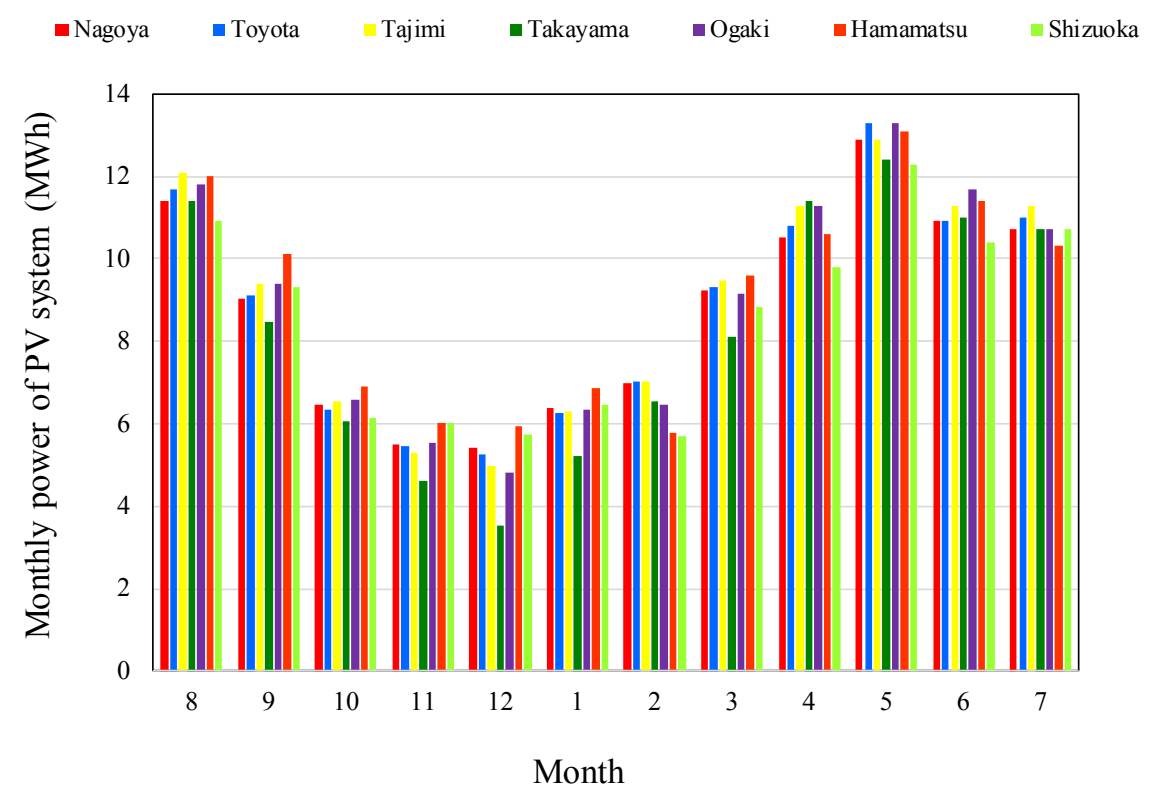

Figure 2. Monthly power of PV system assumed to be installed in seven cities. 
Table 2. Hourly power of PV system assumed to be installed in Nagoya for a year (Unit: $\mathrm{kW} \cdot \mathrm{h})$.

\begin{tabular}{|c|c|c|c|c|c|c|c|c|c|c|c|c|}
\hline $\begin{array}{l}\text { Time } \\
\text { (h) }\end{array}$ & $\begin{array}{l}\text { Aug, } \\
2013\end{array}$ & $\begin{array}{l}\text { Sep, } \\
2013\end{array}$ & $\begin{array}{l}\text { Oct, } \\
2013\end{array}$ & $\begin{array}{l}\text { Nov, } \\
2013\end{array}$ & $\begin{array}{l}\text { Dec, } \\
2013\end{array}$ & $\begin{array}{l}\text { Jan, } \\
2014\end{array}$ & $\begin{array}{l}\text { Feb, } \\
2014\end{array}$ & $\begin{array}{l}\text { Mar, } \\
2014\end{array}$ & $\begin{array}{l}\text { Apr, } \\
2014\end{array}$ & $\begin{array}{l}\text { May, } \\
2014\end{array}$ & $\begin{array}{l}\text { Jun, } \\
2014\end{array}$ & $\begin{array}{c}\text { Jul, } \\
2014\end{array}$ \\
\hline 0 & 0 & 0 & 0 & 0 & 0 & 0 & 0 & 0 & 0 & 0 & 0 & 0 \\
\hline 1 & 0 & 0 & 0 & 0 & 0 & 0 & 0 & 0 & 0 & 0 & 0 & 0 \\
\hline 2 & 0 & 0 & 0 & 0 & 0 & 0 & 0 & 0 & 0 & 0 & 0 & 0 \\
\hline 3 & 0 & 0 & 0 & 0 & 0 & 0 & 0 & 0 & 0 & 0 & 0 & 0 \\
\hline 4 & 0 & 0 & 0 & 0 & 0 & 0 & 0 & 0 & 0 & 0 & 0 & 0 \\
\hline 5 & 1 & 0 & 0 & 0 & 0 & 0 & 0 & 0 & 0 & 4 & 4 & 6 \\
\hline 6 & 13 & 4 & 3 & 1 & 0 & 0 & 0 & 2 & 7 & 17 & 14 & 13 \\
\hline 7 & 21 & 11 & 12 & 8 & 2 & 3 & 6 & 14 & 22 & 33 & 18 & 23 \\
\hline 8 & 32 & 26 & 25 & 20 & 13 & 14 & 16 & 30 & 35 & 38 & 24 & 38 \\
\hline 9 & 29 & 11 & 22 & 30 & 23 & 26 & 23 & 43 & 42 & 38 & 31 & 34 \\
\hline 10 & 41 & 31 & 22 & 37 & 21 & 35 & 36 & 53 & 46 & 45 & 22 & 41 \\
\hline 11 & 43 & 44 & 29 & 26 & 35 & 40 & 37 & 56 & 52 & 55 & 37 & 47 \\
\hline 12 & 55 & 49 & 29 & 26 & 29 & 23 & 37 & 53 & 57 & 52 & 30 & 60 \\
\hline 13 & 50 & 39 & 22 & 11 & 31 & 21 & 28 & 18 & 48 & 39 & 50 & 49 \\
\hline 14 & 35 & 42 & 20 & 21 & 13 & 27 & 31 & 14 & 34 & 46 & 38 & 22 \\
\hline 15 & 26 & 28 & 12 & 4 & 8 & 15 & 17 & 10 & 19 & 32 & 42 & 13 \\
\hline 16 & 16 & 15 & 7 & 2 & 1 & 3 & 8 & 8 & 7 & 24 & 27 & 6 \\
\hline 17 & 8 & 4 & 0 & 0 & 0 & 0 & 1 & 1 & 3 & 8 & 13 & 6 \\
\hline 18 & 1 & 0 & 0 & 0 & 0 & 0 & 0 & 0 & 0 & 1 & 3 & 2 \\
\hline 19 & 0 & 0 & 0 & 0 & 0 & 0 & 0 & 0 & 0 & 0 & 0 & 0 \\
\hline 20 & 0 & 0 & 0 & 0 & 0 & 0 & 0 & 0 & 0 & 0 & 0 & 0 \\
\hline 21 & 0 & 0 & 0 & 0 & 0 & 0 & 0 & 0 & 0 & 0 & 0 & 0 \\
\hline 22 & 0 & 0 & 0 & 0 & 0 & 0 & 0 & 0 & 0 & 0 & 0 & 0 \\
\hline 23 & 0 & 0 & 0 & 0 & 0 & 0 & 0 & 0 & 0 & 0 & 0 & 0 \\
\hline Total & 370 & 303 & 202 & 185 & 176 & 207 & 241 & 303 & 373 & 431 & 354 & 362 \\
\hline
\end{tabular}

constant value up to the midnight. In addition, it is obvious that the electricity demand is higher in summer and winter, especially at the night in summer. However, it is lower in spring and autumn.

Figure 3 has shown the monthly self-sufficiency rate of the FC system in the 40 house case. The self-sufficiency rate is calculated by dividing the power produced by the FC system by the electricity demand, which is not covered by the PV system. Here, the power produced by the FC system has been calculated by using the surplus power of PV system and the Equations (5) and (6). If the self-sufficiency rate of the FC system is over $100 \%$, the proposed integrated system can cover the electricity demand of households living in the building. In this 
Table 3. Hourly electricity damand data of 40 households (Unit: kW.h).

\begin{tabular}{|c|c|c|c|c|c|c|c|c|c|c|c|c|}
\hline $\begin{array}{l}\text { Time } \\
\text { (h) }\end{array}$ & $\begin{array}{l}\text { Aug, } \\
2013\end{array}$ & $\begin{array}{l}\text { Sep, } \\
2013\end{array}$ & $\begin{array}{l}\text { Oct, } \\
2013\end{array}$ & $\begin{array}{l}\text { Nov, } \\
2013\end{array}$ & $\begin{array}{l}\text { Dec, } \\
2013\end{array}$ & $\begin{array}{l}\text { Jan, } \\
2014\end{array}$ & $\begin{array}{l}\text { Feb, } \\
2014\end{array}$ & $\begin{array}{l}\text { Mar, } \\
2014\end{array}$ & $\begin{array}{l}\text { Apr, } \\
2014\end{array}$ & $\begin{array}{l}\text { May, } \\
2014\end{array}$ & $\begin{array}{l}\text { Jun, } \\
2014\end{array}$ & $\begin{array}{c}\text { Jul, } \\
2014\end{array}$ \\
\hline 0 & 3 & 3 & 3 & 3 & 4 & 4 & 4 & 4 & 4 & 3 & 2 & 3 \\
\hline 1 & 3 & 3 & 3 & 3 & 3 & 4 & 4 & 4 & 4 & 3 & 2 & 3 \\
\hline 2 & 3 & 3 & 3 & 3 & 3 & 4 & 4 & 3 & 4 & 3 & 2 & 3 \\
\hline 3 & 3 & 3 & 3 & 3 & 3 & 4 & 4 & 3 & 4 & 3 & 2 & 3 \\
\hline 4 & 2 & 2 & 3 & 3 & 3 & 4 & 4 & 4 & 4 & 3 & 2 & 2 \\
\hline 5 & 2 & 2 & 2 & 2 & 3 & 4 & 4 & 4 & 2 & 2 & 2 & 2 \\
\hline 6 & 7 & 6 & 7 & 7 & 7 & 8 & 8 & 7 & 8 & 7 & 5 & 6 \\
\hline 7 & 9 & 8 & 8 & 8 & 10 & 13 & 12 & 11 & 9 & 8 & 7 & 8 \\
\hline 8 & 10 & 9 & 8 & 8 & 11 & 14 & 13 & 12 & 9 & 8 & 8 & 9 \\
\hline 9 & 9 & 8 & 8 & 8 & 10 & 13 & 12 & 11 & 9 & 8 & 7 & 8 \\
\hline 10 & 9 & 8 & 8 & 8 & 10 & 12 & 12 & 11 & 9 & 8 & 7 & 8 \\
\hline 11 & 9 & 8 & 8 & 8 & 10 & 12 & 12 & 11 & 9 & 8 & 7 & 8 \\
\hline 12 & 10 & 9 & 8 & 8 & 10 & 12 & 12 & 11 & 9 & 8 & 7 & 8 \\
\hline 13 & 11 & 10 & 8 & 8 & 10 & 12 & 12 & 11 & 9 & 8 & 8 & 9 \\
\hline 14 & 11 & 10 & 8 & 8 & 10 & 12 & 12 & 11 & 9 & 8 & 8 & 9 \\
\hline 15 & 10 & 9 & 8 & 8 & 10 & 12 & 12 & 11 & 9 & 8 & 7 & 9 \\
\hline 16 & 10 & 9 & 8 & 8 & 10 & 12 & 12 & 11 & 9 & 8 & 7 & 8 \\
\hline 17 & 10 & 9 & 8 & 8 & 14 & 17 & 16 & 15 & 9 & 8 & 7 & 8 \\
\hline 18 & 14 & 13 & 13 & 13 & 14 & 17 & 16 & 15 & 15 & 13 & 11 & 12 \\
\hline 19 & 25 & 23 & 19 & 19 & 16 & 19 & 18 & 17 & 22 & 19 & 19 & 22 \\
\hline 20 & 25 & 23 & 18 & 19 & 15 & 18 & 17 & 16 & 21 & 19 & 19 & 22 \\
\hline 21 & 24 & 22 & 16 & 17 & 14 & 17 & 16 & 15 & 19 & 17 & 18 & 21 \\
\hline 22 & 20 & 18 & 15 & 16 & 12 & 15 & 14 & 13 & 18 & 16 & 15 & 17 \\
\hline 23 & 17 & 15 & 15 & 15 & 9 & 11 & 11 & 10 & 17 & 15 & 12 & 14 \\
\hline Total & 257 & 232 & 208 & 214 & 220 & 272 & 259 & 240 & 237 & 211 & 192 & 221 \\
\hline
\end{tabular}

study, it has been assumed that the surplus power of PV system is used to electrolyze water and the $\mathrm{H}_{2}$ produced is stored for fueling the FC to make up the shortage of power during the required time.

According to Figure 3, the monthly power of the FC system is higher in spring and summer, while it is lower in autumn and winter irrespective of cities. It can be considered that the power generation characteristics of FC system follows the power generation profile of the PV system. In addition, it has been seen from Figure 3 that the monthly self-sufficiency rate of the FC system is below $100 \%$ irrespective of the cities. Therefore, the proposed BIPV + FC system is not able to cover completely the electricity demand of 40 households living in the building. 


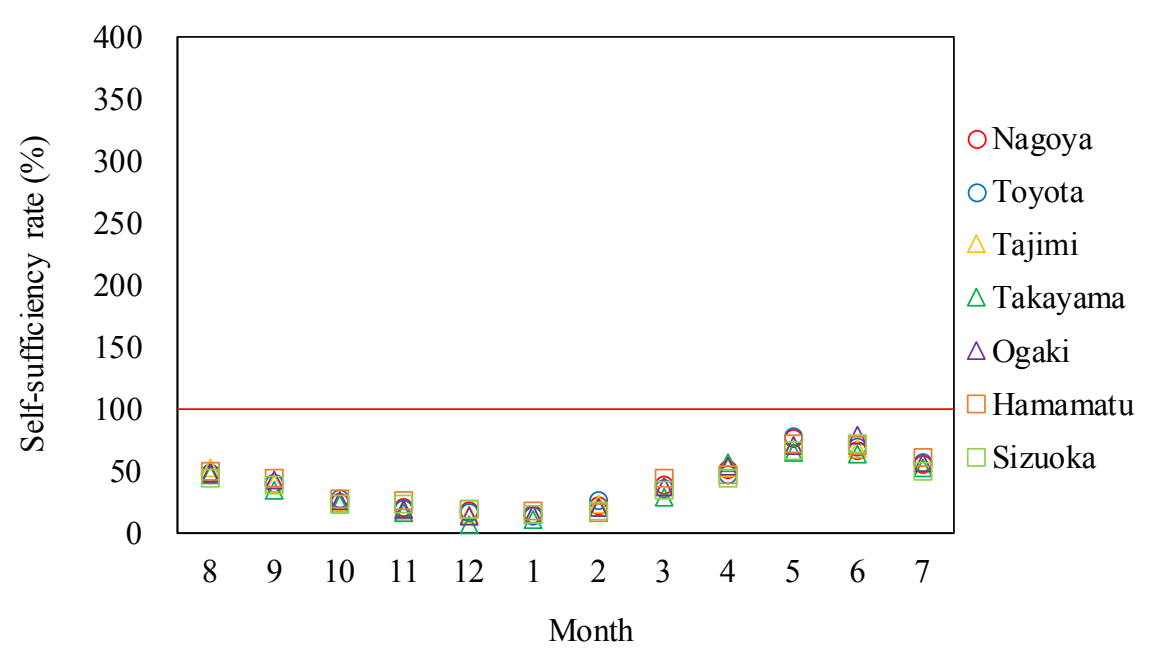

Figure 3. Monthly self-sufficiency rate of the FC system assumed to be installed in seven cities(40 households' case).

\subsection{Optimum Households' Number for Proposed BIPV + FC System to Meet Electricity Demand Completely}

The households' number is changed to investigate the proper households' number for same installment area of solar array on the roof/top of building. Figures 4-6 have shown the monthly self-sufficiency rate of FC system assumed to be installed in Nagoya, Toyota, Tajimi, Takayama, Ogaki, Hamamatsu and Shizuoka for 20, 16 and 12 households' cases, where the stories of buildings are 5, 4 and 3, respectively. Figures 7-9 show the monthly mean temperature, mean wind velocity and sunshine hours [32] whose date and time followed the data base of the project "PV300" [19], respectively.

It can be seen from Figures 4-6, the self-sufficiency rate of FC system is higher with decreasing households' number. This is because that the surplus power of PV system increases with decreasing households' number, i.e., decreasing electricity demand. In addition, the self-sufficiency rate of FC system can be over $100 \%$ in spring and summer while that is below in autumn and winter. This trend matches with the power generation characteristic of PV system. Though the electricity demand increases in summer, the power of PV system seems to be sufficient, resulting in the high self-sufficiency rate of FC system in summer. Comparing seven cities, the self-sufficiency rate of FC system from November to January in Takayama is lower than that in the other cities. Since Takayama has a lot of snow in winter which can be explained by short sunshine hours shown in Figure 9, resulting that the power generated from the PV system is smaller compared to the other cities. Though the monthly mean temperature in winter is lower in Takayama as shown in Figure 7, it is not effective to increase the power generation from the PV system. Therefore, the power generated from FC system decreases due to less $\mathrm{H}_{2}$ generated. The self-sufficiency rate of FC system in Hamamatsu is high through the year, and it is over $100 \%$ even in winter for the 12 households' case. Hamamatsu has long sunshine hours through the year 


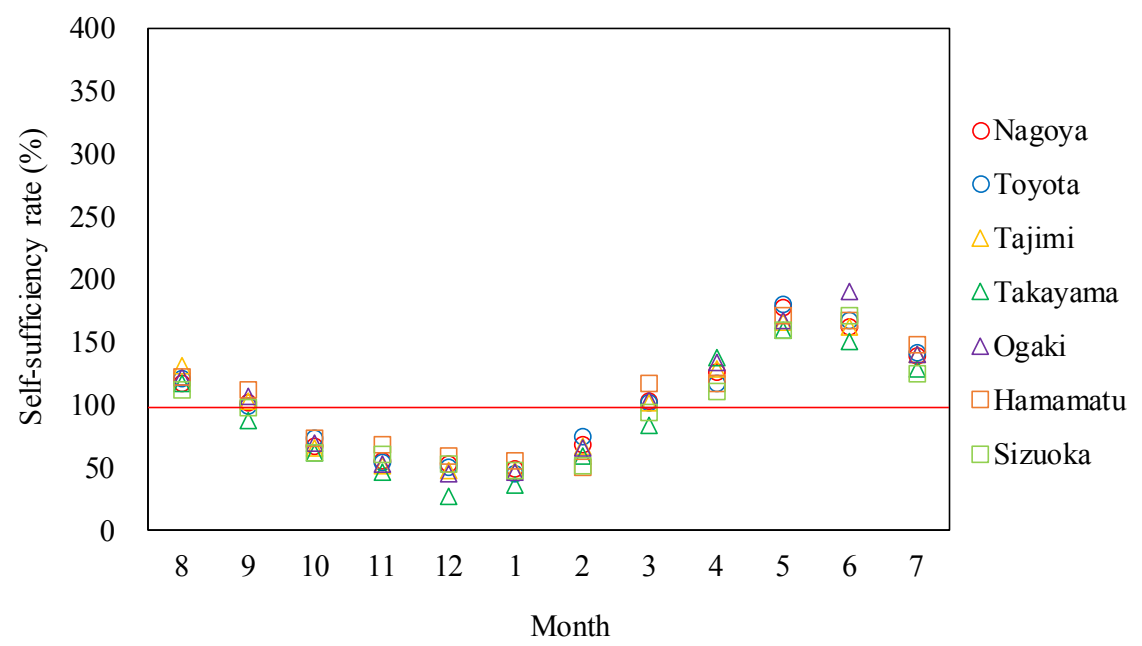

Figure 4. Monthly self-sufficiency rate of the FC system assumed to be installed in seven cities(20 households' case).

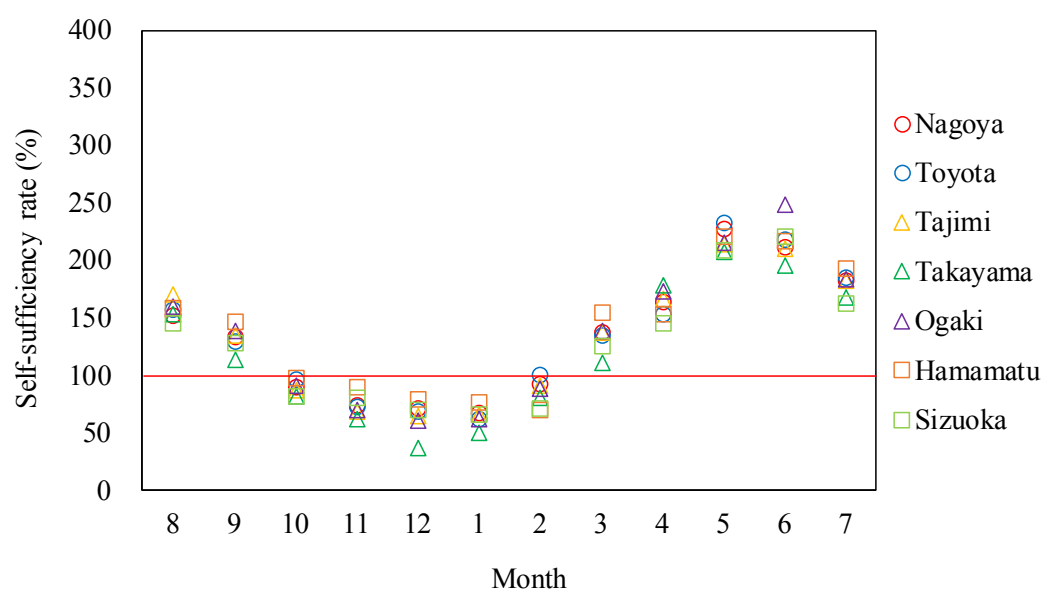

Figure 5. Monthly self-sufficiency rate of the FC system assumed to be installed in seven cities (16 households' case).

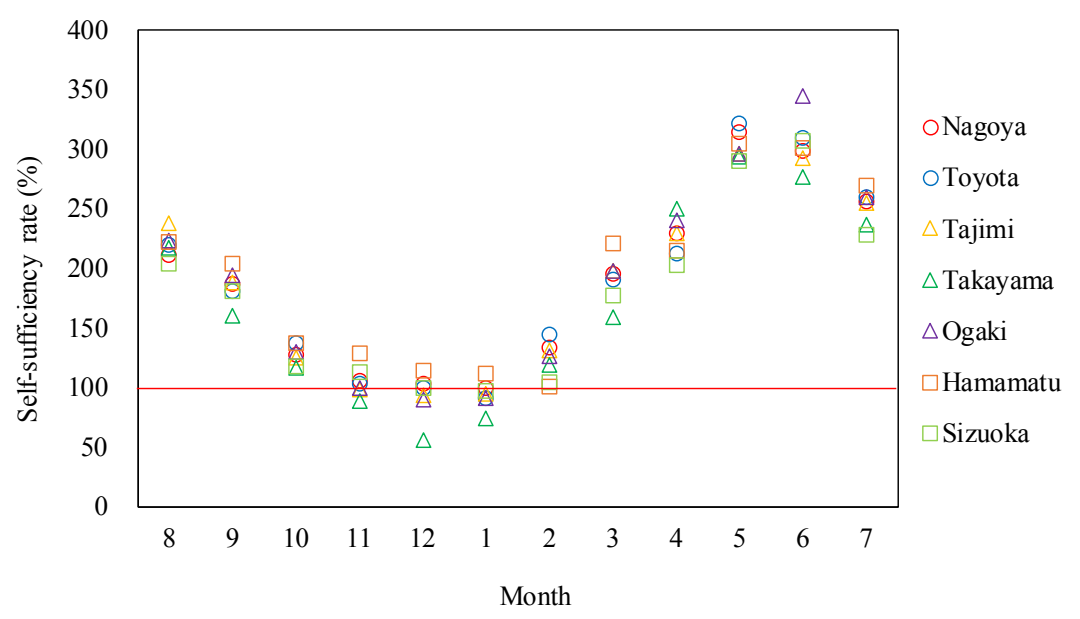

Figure 6. Monthly self-sufficiency rate of the FC system assumed to be installed in seven cities (12 households' case). 


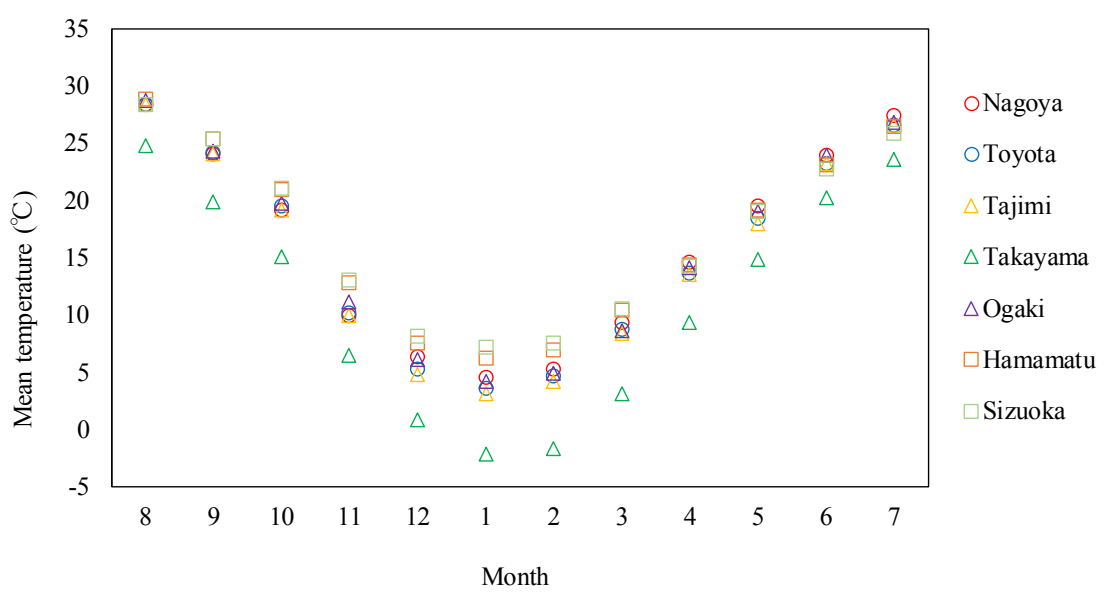

Figure 7. Monthly mean temperature in seven cities.

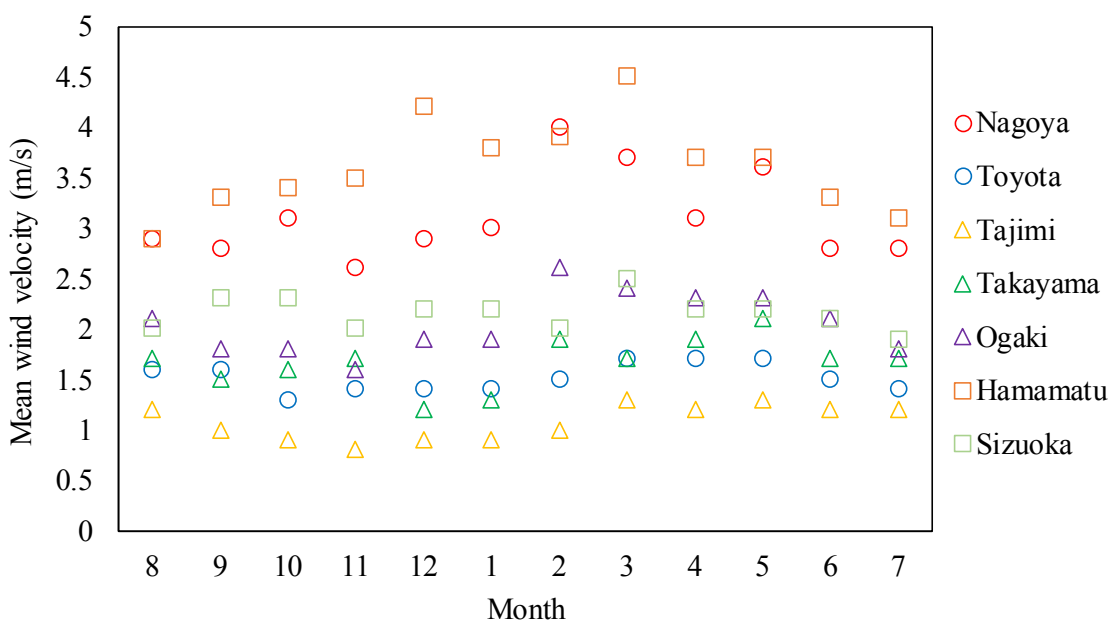

Figure 8. Monthly mean wind velocity in seven cities.

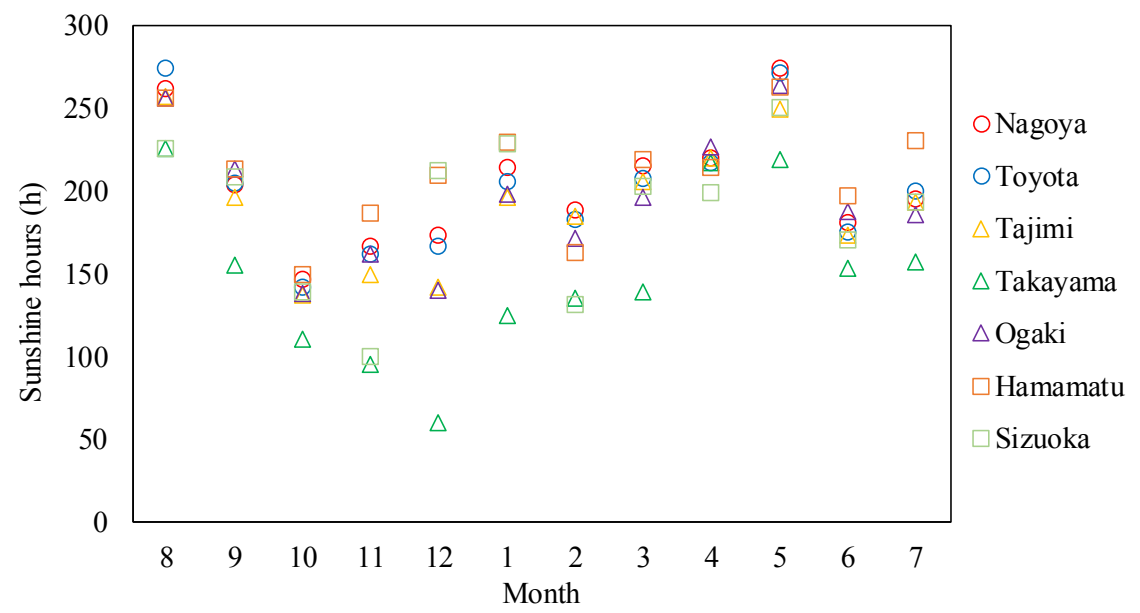

Figure 9. Monthly sunshine hours in seven cities.

according to Figure 9. Furthermore, Hamamatsu has the highest monthly mean wind velocity through the year among seven cities. Strong wind prevents the 
temperature of the PV modules installed from increasing, thus the power generated by the PV system increases, according to Equations (1), (2), (3) and (4).

Figure 10 shows the annual self-sufficiency rate of FC system assumed to be installed in Nagoya, Toyota, Tajimi, Takayama, Ogaki, Hamamatsu and Shizuoka for 40, 20, 16 and 12 households' cases. Though the monthly self-sufficiency rate varies, the surplus $\mathrm{H}_{2}$ obtained in the month whose monthly self-sufficiency rate is over $100 \%$ can be stored and provided for the month whose monthly self-sufficiency rate is below $100 \%$. Therefore, the annual self-sufficiency rate of FC system is a good indicator to determine the optimum households' number which can cover the electricity demand through the year.

According to Figure 10, the annual self-sufficiency rates of FC system for 16 and 12 households' cases are over $100 \%$ irrespective of considered cities. Since it is better to provide the power to many households, this study has decided that 16 households' ( $=4$ stories) case is the optimum for the proposed BIPV + FC system. In addition, it is observed that the self-sufficiency rate of FC system for 20 households is over $100 \%$ in Hamamatsu. Therefore, Hamamatsu is the most appropriate city for installing the proposed BIPV + FC system among the seven cities studied.

The correlation between the households' number and self-sufficiency rate of FC system per solar PV installation area for two cities in Aichi Prefecture, three cities in Gifu Prefecture and two cities in Shizuoka prefecture has been shown in Figures 11-13, respectively. In these figures, the regression formula of the approximate curves and $R^{2}$ error are also shown.

Formula show the correlation between the households' number and self-sufficiency rate of FC system per solar PV installation area can be expressed in the form of $y=a x^{b}$ well. It might be thought that the self-sufficiency rate of

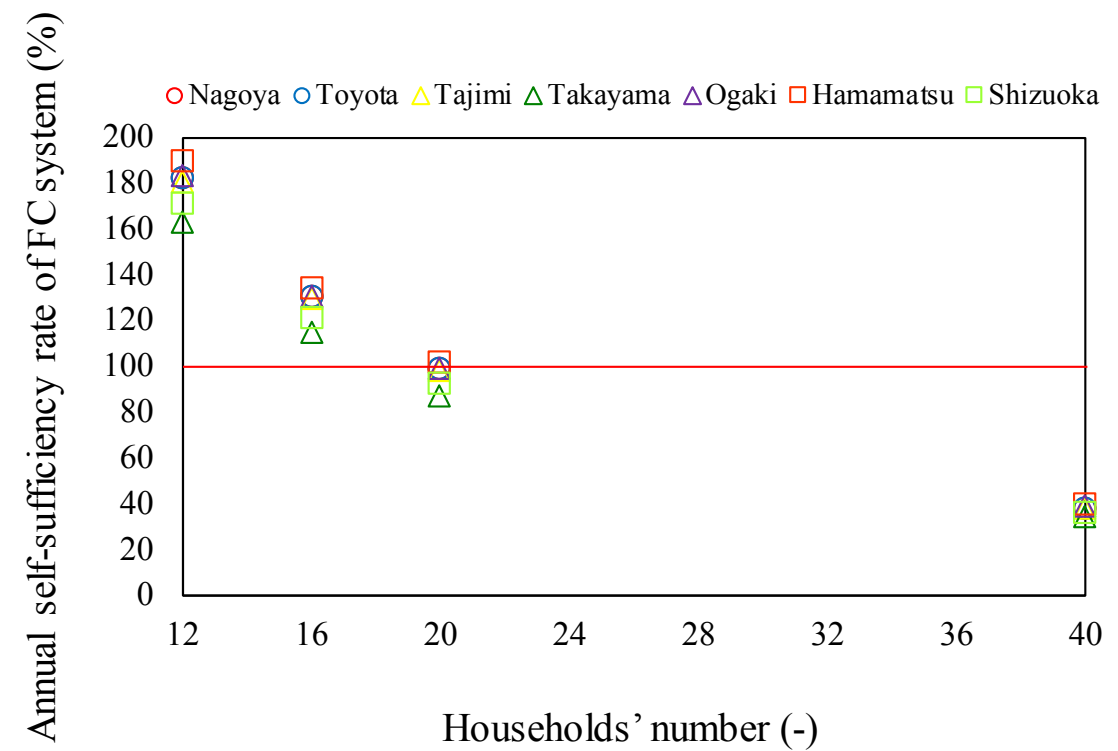

Figure 10. Annual self-sufficiency rate of FC system assumed to be installed in seven cities. 


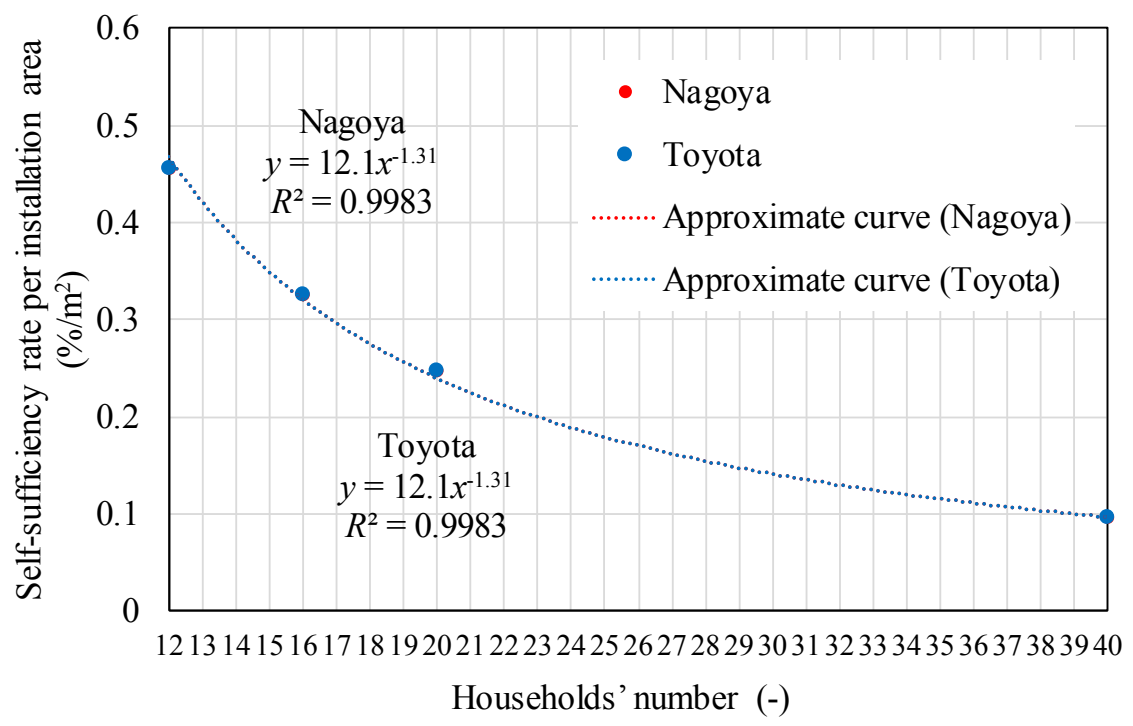

Figure 11. Relationship between the households' number and self-sufficiency rate of FC system per solar PV installation area (Aichi prefecture). The correlation between the households' number and self-sufficiency rate of FC system per solar PV installation area can be expressed in the form of $y=a x^{b}$ well. $R^{2}$ error is very small.

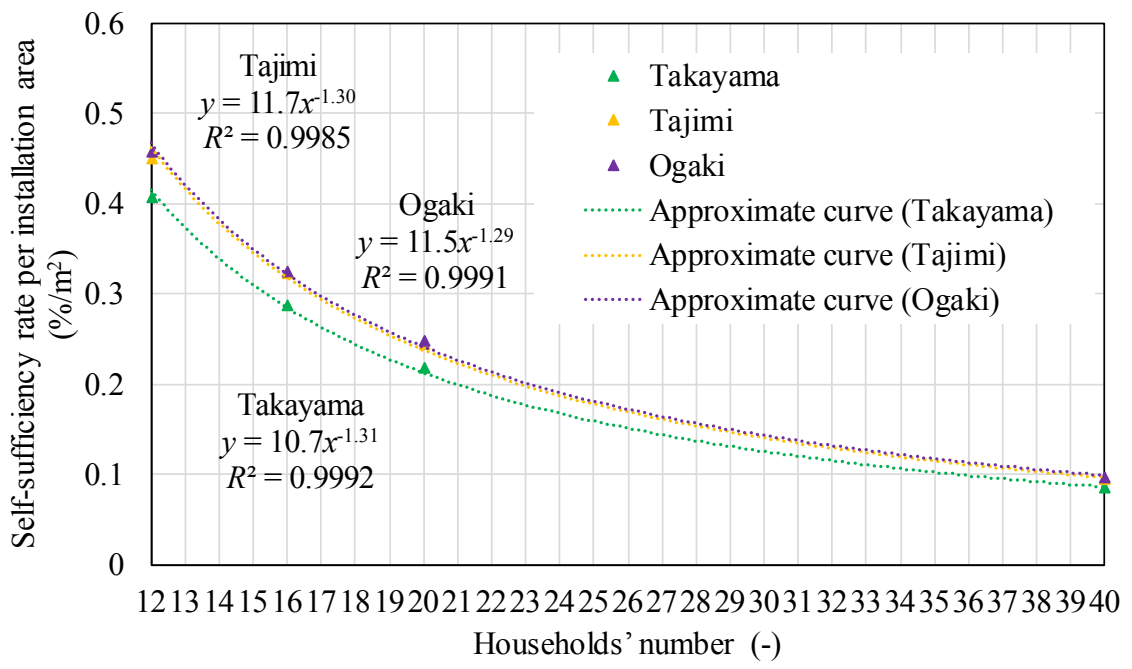

Figure 12. Relationship between the households' number and self-sufficiency rate of FC system per solar PV installation area (Gifu prefecture). The correlation between the households' number and self-sufficiency rate of FC system per solar PV installation area can be expressed in the form of $y=a x^{b}$ well. $R^{2}$ error is very small.

FC system per solar PV installation area will increase for the households' number which is smaller than 12 . However, this study assumed that the lowest limit of stories were set 3 which was the standard low height building. Therefore, this study hasn't considered the case for households' number which is smaller than 12 .

\section{Conclusions}

This study has proposed an integrated BIPV + FC system for Japanese buildings. 


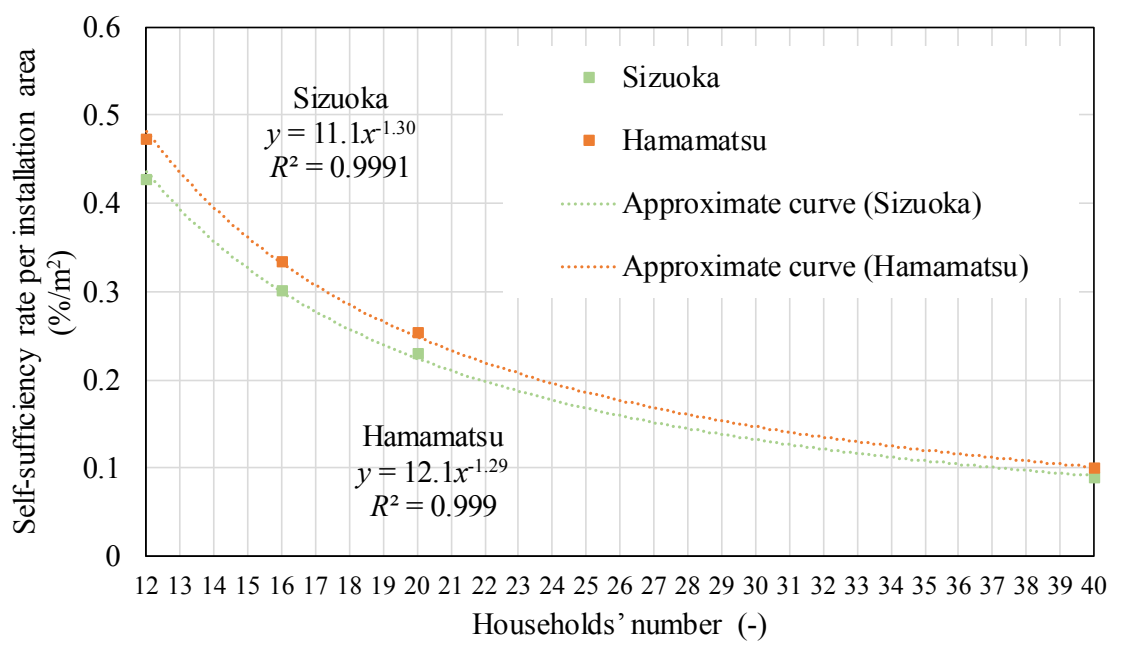

Figure 13. Relationship between the households' number and self-sufficiency rate of FC system per solar PV installation area (Shizuoka prefecture). The correlation between the households' number and self-sufficiency rate of FC system per solar PV installation area can be expressed in the form of $y=a x^{b}$ well. $R^{2}$ error is very small.

The FC is fueled by $\mathrm{H}_{2}$ which is generated from the surplus power generated from BIPV through electrolytic process. The self-sufficiency rates of the FC have been investigated using meteorological data of two cities in Aichi prefecture (Nagoya, Toyota), three cities in Gifu prefecture (Tajimi, Takayama, Ogaki) and two cities in Shizuoka prefecture (Hamamatsu, Shizuoka) of Japan to understand the impact of local climate condition on the performance of the proposed system as well as to find out a universal system model. As a result, the following conclusions have been drawn from the study:

1) The annual self-sufficiency rates of FC system for 16 and 12 households' cases are over $100 \%$ in all cities studied. Therefore, 16 households (= 4 stories) are thought to be the optimum households' number for the proposed BIPV + FC system.

2) Hamamatsu is the most appropriate city for installing the proposed BIPV + FC system among the seven cities studied.

3) The correlation between the households' number $(x)$ and self-sufficiency rate of FC system per solar PV installation area $(y)$ can be expressed in the form of $y=a x^{b}$ well, where $a$ and $b$ depend on the locations/cities.

\section{References}

[1] Agency for Natural Resources and Energy (2017) Energy White Paper 2017. http://www.enecho.meti.go.jp/about/whitepaper/2017pdf/whitepaper2017pdf_2_2.p df

[2] Jelle, B.P. (2016) Building Integrated Photovoltaics: A Concise Research Pathways. Energies, 9, 1-30.

[3] Tripathy, M., Sadhu, P.K. and Panda, S.K. (2016) A Critical Review on Building Integrated Photovoltaic Products and Their Applications. Renewable and Sustainable 
Energy Reviews, 61, 451-465. https://doi.org/10.1016/j.rser.2016.04.008

[4] Zomer, C., Nobre, A., Reindl, T. and Ruther, R. (2016) Shading Analysis for Rooftop BIPV Embedded in a High-Density Environment: A Case Study in Singapore. Energy and Buildings, 121, 159-164. https://doi.org/10.1016/j.enbuild.2016.04.010

[5] Humada, A.M., Hojabri, M., Hamada, H.M. and Samsuri, F.B. (2016) Performance Evaluation of Two Technologies (c-Si and CIS) for Building Integrated Photovoltaic Based on Tropical Climate Condition: A Case Study in Malaysia. Energy and Buildings, 119, 233-241. https://doi.org/10.1016/j.enbuild.2016.03.052

[6] Davi, G.A., Caamano-Martin, E., Ruther, R. and Solano, J. (2016) Energy Performance Evaluation of a Net Plus-energy Residential Building with Grid-Connected Photovoltaics System in Brazil. Energy and Buildings, 120, 19-29. https://doi.org/10.1016/j.enbuild.2016.03.058

[7] Burg, B.R., Ruch, P., Paredes, S. and Michel, B. (2017) Effects of Radiative Forcing of Building Integrated Photovoltaic Systems in Different Urban Climates. Solar Energy, 147, 399-405. https://doi.org/10.1016/j.solener.2017.03.004

[8] Lamnatou, C., baig, H., Chemisana, D. and Malick, T.K. (2017) Dielectric-Based 3D Building-Integrated Concentrating Photovoltaic Modules: An Environmental Life-Cycle Assessment. Energy and Buildings, 138, 514-525.

https://doi.org/10.1016/j.enbuild.2016.12.038

[9] Sagani, A., Mihelis, J. and Dedoussis, V. (2017) Techno-Economic Analysis and Life-Cycle Environmental Impacts of Small-Scale Building-Integrated PV Systems in Greece. Energy and Buildings, 139, 277-290.

https://doi.org/10.1016/j.enbuild.2017.01.022

[10] Davi, G.A., Asiain, J.L., Solano, J. and Caamano-Martin, E. (2017) Energy Refurbishment of an Office Building with Hybrid Photovoltaic System and Demand-Side Management. Energies, 10, 1117. https://doi.org/10.3390/en10081117

[11] Uddin, K., Gough, R., Radcliffe, J., Marco, J. and Jennings, P. (2017) Techno-Economic Analysis of the Viability of Residential Photovoltaic Systems Using Lithium-Ion Batteries for Energy Storage in the United Kingdom. Applied Energy, 206, 12-21. https://doi.org/10.1016/j.apenergy.2017.08.170

[12] Kumagaki, H. (2016) Renewable Energy Mass Transportation Based on Methanation Technology. Preprints of the 3rd Hydrogen Energy Lecture Meeting of the Japan Society Energy, Tokyo, 16 December 2016, 24.

[13] Gonzalez, E.L., Llerena, F.I., Perez, M.S., Iglesias, F.R. and Macho, J.G. (2015) Energy Evaluation of a Solar Hydrogen Storage Facility: Comparison with Other Electrical Energy Storage Technologies. International Journal of Hydrogen Energy, 40, 5518-5525. https://doi.org/10.1016/j.ijhydene.2015.01.181

[14] Marchenko, O.V. and Solomin, S.V. (2017) Modeling of Hydrogen and Electrical Energy Storage in Wind/PV Energy System on the Lake Baikal Coast. International Journal of Hydrogen Energy, 42, 9361-9370. https://doi.org/10.1016/j.ijhydene.2017.02.076

[15] Barumann, L. and Boggasch, E. (2016) Experimental Assessment of Hydrogen Systems and Vanadium-Redox-Batteries for Increasing the Self-Consumption of Photovoltaic Energy in Buildings. International Journal of Hydrogen Energy, 41, 740-751. https://doi.org/10.1016/j.ijhydene.2015.11.109

[16] Khalid, F., Dincer, I. and Rosen, M.A. (2016) Analysis and Assessment of an Integrated Hydrogen Energy System. International Journal of Hydrogen Energy, 41, 7960-7967. https://doi.org/10.1016/j.ijhydene.2015.12.221 
[17] Singh, A., Baredar, P. and Gupta, B. (2017) Techno-Economic Feasibility Analysis of Hydrogen Fuel Cell and Solar Photovoltaic Hybrid Renewable Energy System for Academic Research Building. Energy Conversion and Management, 145, 398-414. https://doi.org/10.1016/j.enconman.2017.05.014

[18] Nishimura, A., Kitagawa, S., Hirota, M. and Kolhe, L.M. (2017) Energy Assessment of Building Integrated Photovoltaics and Fuel Cell Systems: Design Study for Buildings(s) of Mie, Japan. Smart Grid and Renewable Energy, 8, 129-144. https://doi.org/10.4236/sgre.2017.85009

[19] Chubu Electric Power (2014) The Irradiance Data of the Project "PV300" (Electric Data Base).

[20] The Society of Heating, Air-Conditioning and Sanitary of Engineering of Japan (1998) Assessment, Plan and Design of Co-Generation System by City Gas. Maruzen, Tokyo.

[21] Nishimura, A., Ito, T., Kakita, M., Murata, J., Ando, T., Kamada, Y., Hirota, M. and Kolhe, M. (2014) Impact of Building Layout on Wind Turbine Power Output in the Built Environment: A Case Study of Tsu City. Journal of the Japan Institute of Energy, 84, 315-322. https://doi.org/10.3775/jie.93.315

[22] Ministry of Internal Affairs and Communications (2017) Dwelling by Area of Floor Space (6 Groups) an Tenure of Dwelling (2 Groups)-Japan, 3 Major Metropolitan Areas, Prefectures and Major Cities (1998-2008). http://www.e-stat.go.jp/SGI/estat/ListE.do?bid=000001029530\&code $=0$

[23] Nishimura, A., Kitagawa, S., Hirota, M. and Hu, E. (2017) Assessment on Energy Self-Sufficiency Rate for Building Integrated Photovoltaics and Fuel Cell System in Japan. Smart Grid and Renewable Energy, 8, 195-211. https://doi.org/10.4236/sgre.2017.86013

[24] New Energy and Industrial Technology Development Organization of Japan (2017) Guideline on Field Test Project of Photovoltaic Power Generation for Design, Construction and System. http://www.nedo.go.jp/content/100110086.pdf

[25] Panasonic (2018) Products Lineup. http://sumai/panasonic.jp/solar/lineup.html

[26] Panasonic (2018) Power Conditioner with High Conversion Efficiency. https://sumai.panasonic.jp/solar/need_power_conditioners.html

[27] Kawamoto, K., Nakatani, S., Hagihara, R. and Nakai, T. (2002) High Efficiency HIT Solar Cell. Sanyo Technical Review, 34, 111-117.

[28] Oozeki, T., Izawa, T., Otani, K., Tsuzuki, K., Koike, H. and Kurokawa, K. (2005) An Evaluation Method for PV Systems by Using Limited Data Item. IEEJ Transaction on Power Energy, 125, 1299-1307. https://doi.org/10.1541/ieejpes.125.1299

[29] IHT (2018) Technical Information/Benefits of IHT’s Electrolysers. http://www.iht.ch/technologie/electrolysis/industry/technical-information-benefitselectrolysers.html

[30] Kato, T. (2015) Possibility of Hydrogen Production from Renewable Energy. Journal of Japan Institute of Technology, 94, 7-18.

[31] Panasonic (2018) Specification of ENEFARM. https://panasonic.biz/appliance/FC/house_07.html

[32] Japan Meteorological Agency (2018) Past Meteorological Data Search. http://www.data.jma.go.jp/obd/stats/etrn/index.php 